\title{
Global Challenges in Democratic Local Governance of the African States
}

\author{
Remi Chukwudi Okeke ${ }^{1 *}$ Sylvia Uchenna $\mathrm{Agu}^{2}$ \\ ${ }^{1,2}$ Department of Public Administration and Local Government, \\ University of Nigeria, Nsukka \\ aremiokeke@gmail.com, ${ }^{\mathrm{b}}$ uchesagu@yahoo.com
}

Keywords: African states, Democracy, Local governance, European region, Self-Government

\begin{abstract}
Local governments in many parts of Africa are yet to be fully accepted as important levels of government (by political actors at the central and sub-central levels). This gives rise to the contradictory scenario whereby such political actors at the central and sub-central levels remain the apostles of centralization on one hand and exponents of democracy as a model of national government on the other hand. Nigeria is the most populous African country. And this marginalization of the local government in the democratic process is prevalent in Nigeria. Invariably, the pervasive effect of this condition, as it negatively affects the availability of dividends of democracy to the African citizen, is worrisome. In the meantime, the continent of Europe is perceived in the study as having possibly taken local government understanding to a model level of local self-governance, through its European Charter of Local Self-Government. Europe is thus, seen in this study as a region in the lead in situating the local government paradigm, within its proper democratic context. The theoretical framework of deliberative democracy is adopted in the study to engage African states to embrace local self-governance as a critical component of democratization.
\end{abstract}

\section{Introduction}

Local-Central Government relations have indeed, globally been characterized by disharmony. Local and central governments, argues Marsh [1] do not always see eye to eye. In the process, the contributions, which local governments can make to national democratic processes become stunted. Invariably, the global developmental process remains impaired. Moreover, according to Reid [2], the manner in which central and local governments engage, has taken on extra salience in recent years, as governments seek to address critical issues and begin to appreciate the role of place, as a key contributor of economic growth. Reid further highlights that finding the appropriate mix of roles between local and central governments is necessary, as the business of governing requires an ability to balance the differing needs and expectations of both local and national communities. Furthermore (in global perspectives), in New Zealand, which (even though) has an established system of local government, there is very little local power. The local government system in this country is still highly reliant on the center [2].

Specifically in Africa (in Zimbabwe, Southern Africa) Marumahoko and Fessha [3] strongly believe there is a growing realization in local-central government relations that urbanization has overstretched the ability and efforts of the central government, to serve from the centre, giving rise to the search for a robust decentralization policy, which vests urban local governments with some level of autonomy. In this context, decentralization has become critical in the quest to respond to the varied service-delivery challenges brought about by increasing urbanization.

From the United Republic of Tanzania (East Africa), the President's Office, in charge of Regional Administration and Local Government highlights that Local Government Authorities operated under severe financial constraints. Underfunding was significant and with respect to revenue, Local Authorities had sources that were generally difficult to collect. The Local Authorities were accordingly non-buoyant. There was interference by Central Government agencies in revenue collection by Local Government Authorities...Lastly; there was no institutional mechanism to facilitate rational decisions about sharing public revenue sources, particularly funds distributable between the Central and Local Governments. Consequently, Central Government 
transfers to Local Governments remained inadequate and arbitrary [4]. Hussein [5] sees the scenario in Egypt (North Africa) as where local administration is a hub for corruption but if reformed and decentralized, it can improve the state's governance, democracy and the quality of public services.

It is therefore against the foregoing background that this paper sets out to study the global challenges in democratic local governance. Deliberative democracy is the theoretical framework of our analysis as this theory refers to a school of thought in political studies, which holds that political decisions should be the product of fair and reasonable discussion and debate among citizens. Deliberation thus becomes a necessary precondition for the legitimacy of democratic political decisions. Rather than thinking of political decisions as the aggregate of citizens' preferences, deliberative democracy holds that citizens should arrive at political decisions through reason and the collection of competing arguments and viewpoints. Deliberation (in democratic processes) thus generates outcomes that secure the public or common good, through reason rather than through political power [6].

\section{Statement of the Problem}

Local government has been defined as government by popularly elected bodies charged with the administrative and executive duties in matters concerning the inhabitants of a particular district or place [7]. According to Alicia [8] the local level is where we live, raise our families and walk the streets. Consequently, government at local level touches our lives far more openly and far more directly than other levels of government. The Guidelines for local government reform [9] in Nigeria cited by Panter-Brick [10] also states that local government implies governing at the grassroots or local level. Thus, a critical look at the three positions cited above shows some allusion to the notion of giving room for local discretion and popular participation in governance at the local level this refers to deliberative democracy. Yet, African states at national and sub-national levels tend to continue to prevaricate over notions of local government, which contain as core values, local discretion and popular participation; even when a corollary to local government is the concept of local self-government (which is more progressive and immensely democratic). Indeed, what has remained in place in Africa is widespread centralization in local government matters, a development that has been attributed to colonial hangover [11].

Therefore, if the post-independence African states have continued to embrace centralization, as illustrated in the Zimbabwean, Tanzanian and Egyptian cases, is it for what purpose? Why is the African political leader, apprehensive of local self-government? Is it because, as Wanjohi [11] has contended, that they fear challenges that strong local authorities could pose to national governments, in terms of the political power the local governments would wield - and the amount of resources they would control - such fears being associated with the problem of the shaky legitimacy of many national governments in Africa? Yet, Appadorai [7] has argued that local self-government does not mean that the local bodies are free from all controls by the central government.

Does the solution lie with the contention of Lyons [12] to the effect that central governments need to leave more room for local discretion and recognize the value of local choice? While local government needs to strengthen its own confidence and capability, engage more effectively with local people, make the best use of existing powers, and stop asking for central direction. The problematic question however is: how can this position - of Lyons [12] become embraced by African states, especially the leading states like Nigeria (the most populous state in Africa)? Lyons subsequently tables place-shaping as solution - using powers and influence creatively, to promote the well-being of the community and its citizens. Place-shaping, Lyons further contends, is to be a shared agenda to which the local and central government will bring particular skills and advantages. Then the next critical question is this: what particular skills can the current local authorities in Africa bring to a place-shaping agenda? What particular advantages from the local authorities can the overbearing central authorities not equally claim to possess? There is therefore, a general lack of holistic approach to local government issues by African states, as we shall soon illustrate with the situation in Nigeria. 
Curiously in Africa, a holistic approach to local governance has rather been equated to centralization. But over-centralization is antithetical to the tenets of strong local governance and invariably, local self-governance, which exemplifies democracy (deliberative democracy), democracy currently being the model system of government at local, national and supra-national levels. Invariably, Local government is about local self-government, which has its pillar in democracy and democratization [13]. Hence, the absence of local self-governance in African states partly accounts for the inability of these states to fully galvanize the citizenry for spirited contributions to the course of national growth and development.

\section{Critical Analysis of the Challenges in Local Governance in Africa: The Nigerian Dimension}

The local government is the third tier of the three-tier system of government in Nigeria. The others are the federal (central) and the state governments (36 states in number). There are in Nigeria, 774 Local Government Areas, recognized by the subsisting 1999 Constitution. Hence, these elaborate governance structures entail inter-governmental relations which effectiveness should have led to overall good governance. However, hiccups in inter-governmental relations in Nigeria have rather led to an abysmal performance by government, especially at local government level. According to Onah [14], the treatment of local governments as appendages or state extensions rather than tiers of government that can effectively play their part in intergovernmental relations had continued unabated in Nigeria. Consequently, local governments are given funds that can barely pay staff salaries and other overhead costs, thus imperiling development activities that constitute reasons for the existence of the local governments. In fact, posits Onah [15] the local government in Nigeria remains an instrument of the state governments, as incidentally spelt out in the forward to the guidelines of the 1976 local government reform in the country.

Hence, what has subsequently featured in Nigeria's local government reforms is the issue of decentralization as local self-governance. But decentralization is conceptually distinct from local self-governance. Akinola [16] has on this issue succinctly elucidated as follows: The two may embrace one another if the operators mean well. It is possible for decentralization structures to accommodate the self-governing principle. However, post-independence African governments have tended to exclude the elements of self-governance from their concept of decentralization. And according to Laski [17] it is becoming generally recognized that efficient administration is impossible unless the diffusion of power creates a wide sense of responsibility, as men who do no more than carry out the will of others, soon cease to be interested in the process of which they are part. Laski contends that a local authority, which has the power to make mistakes, is more likely to do useful work than a local authority that merely carries out the will of a central body.

In Nigeria therefore, the local authority (local government) merely carries out the will of the state government. Thus, the capacity of the various local governments to do useful things has remained questionable. In the process, democratic ideals and local government practices work at cross-purposes. Deliberative democracy is non-existent. We consequently opine in this regard that the local government setting is the most profound ground for deliberative democracy in Nigeria. But deliberative democracy (at the local government level) is truly not embraced in Nigeria and indeed in all the other African states that have been sampled for this study. Deliberation in democratic processes generates outcomes that secure the public or common good through reason rather than through political power [6].

In addition, deliberative democracy guarantees that the voices of the local citizens are heard, on matters that affect the citizens, as different from ordinarily decentralized systems where the local elite would still be in biased control. Furthermore, on this score, as Akinola [16] has highlighted, political leaders at the local level in Nigeria could be described as predators of public resources meant for the benefits of all. And Nigeria is now faced with a dreary situation whereby what is in place as local government cannot be strictly called local government, even though elections had been conducted and concluded for such purposes. Hence, according to Mukanova [18], if an elected body (local government) is not able (no matter what the reasons are) to provide services, it can hardly be called local government. 
We further highlight in agreement with Ikemitang [19] that the local government system in Nigeria has not been fundamentally reformed, particularly in the area of decentralization and local self-governance. According to Ikemitang, with the array of functions to be performed by the Local Government Councils in Nigeria, as enshrined in the 1999 Constitution, more powers should be devolved to the Local Government Councils, such as the granting of financial autonomy, to enable the Local Councils live up to their responsibilities.

Ogban-Iyan and Chukwu [20], argue that apart from the federal government, which enjoys unimpeded autonomy and sovereignty in the Nigerian federation, both the states and local governments only enjoy limited autonomy within their respective areas of governance. And another name for this situation of course is centralization. We therefore opine that there should be effective decentralization of the system but above all, the decentralization that holds deliberative democracy as core value, not decentralization that still leaves local governance and provision of services (at the local level), in the hands of some insensitive and greedy elite. In essence, a major problem with the centralized system has to do with its elite dominance. Okeke [21] has amply demonstrated that elite dominance is a major debilitating issue in the Nigerian political system.

\section{Local Self-Governance as Global Trend}

One easily noticeable trend in the subject of local government is the global gravitation towards local self-government $[11,12,16,18]$. The view has also been expressed that local government is about local self-government, which has its pillar in democracy and democratization [13]. As Teune [22] has also opined, for democracy to become stabilized in institutions, processes and values, it must be part of every day life in localities and their communities. And this is what local self-government has as objective.

In Nepal (South Asia), the enactment of the Local Self-Governance Act (LSGA) in 1999 expanded the mandates of local bodies, devolving the powers, responsibilities and resources required to allow local governments to meet the basic infrastructure needs of the locality. It also called for a greater role for civil society in the everyday functions of local bodies, emphasizing transparency, public accountability and popular participation [23]. There is therefore in Nepal an obvious positive intention to embrace a culture of local self-governance. In Kyrgyzstan (Central Asia), the enabling Local Government Law is overtly denoted as local self-government legislation. In Article 1(1) of the Law of the Kyrgyz Republic about Local Self-Government (2011), the state guarantees the right of local communities on self-government [24]. In essence, wherever democracy is currently preached, local self-governance would sooner than later follow as desirable tendency. We accordingly denote local-self governance as a global trend in this study.

\section{Any Lessons from the Europe Region}

The possible lessons from Europe (for African states) in local (self) government find their most potent interrogation in the European Charter of Local Self-Government. The European Charter essentially commits the parties to applying basic rules guaranteeing the political, administrative and financial independence of local authorities. It is thus a demonstration at European level, of the political will to give substance at all levels of territorial administration, to the fundamental principles of democracy upheld by the Council of Europe since its foundation in 1949. It embodies the conviction that the degree of self-government enjoyed by local authorities may be regarded as a touchstone of genuine democracy [25].

In more specific terms, Article 3(1) of the Charter stipulates that local self-government denotes the right and the ability of local authorities, within the limits of the law, to regulate and manage a substantial share of public affairs, under their own responsibility and in the interests of the local population. Article 3(2) further enshrines as follows: this right shall be exercised by councils or assemblies composed of members freely elected by secret ballot, based on direct, equal, universal suffrage, and which may possess executive organs responsible to them. This provision shall in no way affect recourse to assemblies of citizens, referendums or any other form of direct citizen 
participation where it is permitted by statute. Article 4(4) further provides that powers given to local authorities shall normally be full and exclusive. They may not be undermined or limited by another (central or regional) authority except as provided for, by the law. According to Article 4(5), where a central or regional authority delegates powers to them, local authorities shall insofar as possible, be allowed discretion in adapting their exercise to local conditions. Article 4(6) also holds that local authorities shall be consulted, insofar as possible, in due time and in an appropriate way in the planning and decision-making processes for all matters which concern them directly [26].

Against the African background, the enunciations of the European Charter indeed present daunting challenges. The provisions are clearly against centralization. The decentralization nuances of the provisions are also completely definitive. Furthermore, in the context of this paper, the provisions of the European Charter equally encourage, even if not in express terms, deliberative democracy. We further emphasize that Article 3(1) of the European Charter promotes the ability of local authorities, within the limits of the law, to regulate and manage a substantial share of public affairs, under their own responsibility and in the interests of the local population. In the African context, specifically in the Nigerian federation, what turns the supposed ability into disability is the inferior status accorded to the local government councils in fiscal federalism. We emphasize again that Article 4(6) holds that local authorities shall be consulted, insofar as possible, in due time and in an appropriate way, in the planning and decision-making processes for all matters which concern them directly. In the Nigerian state for instance, it is an anathema, in political and administrative tendencies, for local authorities to be consulted by higher levels of government.

And it is indeed, a mark of the strength of the European Charter of Local Self-Government that the promoters of the idea of a World Charter of Local Self Government have borrowed extensively from the structure and contents of the European Charter, as illustrated by Topfer and Hoffschulte [25]. The remaining question becomes: What would be the contribution of the other continents, to the creation of a World Charter of Local Self-Government? What would be the contribution of the African states? From Zimbabwe, Tanzania, Egypt, to Nigeria, African states are still not definitive on local self-government as the pillar of democracy. Will the contributions of African states stop at the orthodoxy of decentralization, devoid of genuine local self-government? We opine that such middle-of-the-road measures do not galvanize the citizenry enough for spirited contributions to the course of national growth and development.

We are of the view that such designs are still elitist at the local level and that the inherent elitism negates the citizens' desire for an accelerated pace of development in these African states. We further opine that local self-governance is the cornerstone of democracy. It is also in tune with the tenets of deliberative democracy, which we have espoused in this paper, as an effective democratic value for national development.

\section{Conclusion}

We have highlighted in the study that (i) local self-government does not entail severance of all ties with the other tiers of government in a nation-state and (ii) local self-government engenders a tradition of honest and efficient local administration, which should be a dividend of democratic local governance. Based on these highlights therefore, we strongly recommend as follows:

(i) Central and regional tiers of government in Africa should strictly begin to see the local government tiers of government as development partners, instead of inferior levels of government.

(ii) The African Union (AU) should mid-wife the production of an African Charter of Local Self-Government, in order to engender among African states, a tradition of honest, efficient and democratic local governance.

(iii) In resource rich states like Nigeria, more of the revenues generated from natural resources should statutorily be availed to local authorities, to enhance the capacity of such local authorities, for effective and efficient service delivery. 
(iv) To engender a culture of robust local self-governance among African states, funding of the activities of local authorities should take a first-line charge from nationally collected pools of funds.

Our thesis therefore is that in many prominent African states, the recent trends in local government have not been spiritedly divorced from the centralizing tendencies of colonial mentality and elite biases. In the process, the desirable governance paradigm of deliberative democracy has not been given adequate trial at the local government level in these states. This study thus states in conclusion that the future face of governance at the global level, that will be fully democratic in structures and nuances will have in its roots, some critical local self-governance content. In order to make strategic contributions to the shaping of this new face of governance therefore, African states would need to fully accept that self-governing local governments generally constitute the defining issues in democratic systems of government.

\section{References}

[1] S. Marsh, (2013): "Managing Council Relationships with Central Governments". http://www.theguardian.com. Accessed, 07/05/14.

[2] M. Reid, (2012): "Managing Central-Local Government Relationships: The Case of New Zealand" Commonwealth Journal of Local Governance Issue 11: December 2012 http://epress.lib.uts.edu.au/ojs/index.php/cjlg. Accessed, 07/05/14.

[3] S Marumahoko, and Y.T. Fessha, (2011): "Fiscal Autonomy of Urban Councils in Zimbabwe: A Critical Analysis" Law, Democracy \& Development 15 (-) 37-58.

[4]. United Republic of Tanzania (n.d): "History of Local Government in Tanzania" President's office: Regional Administration and Local Government, http://www.pmoralg.go.tz/menudata/aboutus/history/History\%20of\%20Local\%20Government\%20In\%20Tanzania.pdf.

[5] A.M. Hussein, (2012): "The Inevitable Struggle: Local Government in Egypt" http://www.dailynewsegypt.com.

[6] J . L. Eagan, (2013): “Deliberative Democracy”. www.britannica.com.

[7] A. Appadorai, (2004): The Substance of Politics. New Delhi: Oxford University Press.

[8] S.M. Alicia, (2011): "Local Government in North American Context". Public Administration Review. 71(1) 133-136.

[9] FRN (1976): Guidelines for Local Government Reform. Abuja: The Presidency.

[10] K. Panter-Brick, (Ed) (1978): Soldiers and Oil the Political Transformation of Nigeria. London: Frank Cass and Company Ltd.

[11] N.G. Wanjohi, (2000). "Sustainable Local Government and Globalization: The Case of Africa: with Special Reference to Kenya".

http://www.kas.de/uplad/kommuncal/politrik/konferenz-09-2000/wanjohi,pdf, accessed 08/04/11.

[12] M. Lyons, (2006): "National Prosperity, Local Choice and Civic Engagement: A New Partnership between Central and Local Government for the $21{ }^{\text {st }}$ Century".

http://www.yhcoe.rcoe.gov.uk/rce/aio/19407 retrieved 01/04/11

[13] A. Odoh, (2004): "Local Government and Democracy in Nigeria". Nigerian Journal of Public Administration and Local Government, XII (1)175-188.

[14] F.O. Onah, (2004): "Inter-Governmental Relations and the Survival of the Local Governments in the $21^{\text {st }}$ Century Nigeria" Nigerian Journal of Public Administration and Local Government. XII (1)1-16. 
[15] R. Onah, (2004): "Trends in State-Local Government Financial Relations an Local Government Administration in Nigeria". Nigerian Journal of Public Administration and Local Government. XII (1) 189-198.

[16] S.R.Akinola, (2004): "Local Self-Governance as Alternative to Predatory Local Government in Nigeria". International Journal of Studies in the Humanities: 3(1) 47-60.

[17] H.J. Laski, (2008): A Grammar of Politics. Delhi: Surjeet Publications.

[18] N. Mukanova (2008): “Local Self-Government in Kyrgyzstan - Myth or Reality? http://unpanI.un.org/introduc/groups/public/documents/un-dpadm/unpan.

[19] S. Ikemitang, (2013): "Local Government Autonomy: Essential For Grass Roots' Development". http://fmi.gov.ng/features/21495/. Accessed, 08/05/14.

[20] O Ogban-Iyan, and A.A. Chukwu, (2011): “The State Joint Local Government Account and the Fiscal Autonomy of Local Governments in Nigeria: The Case of Enugu State (May 1999May 2007)", in Onyisi, T (ed): Key Issues in Local Government and Development: A Nigerian Perspective. Enugu: Praise house Publishers.

[21] R. C. Okeke, (2014): "Anatomy of the Nigerian Elite: Interrogating a Blind Elite Model of the Elite Theory" European Scientific Journal 10(4) 320-336.

[22] H. Teune, (2000): “Theoretical Foundations of the Democracy and Local Governance Research Programme". http://www.ssc.upenn.edu/dlg/foundation.htn retrieved 31/03/11

[23] The Asia Foundation (2012): "Political Economy Analysis of Local Governance in Nepal" http://aid.dfat.gov.au/Publications/Pages/analysis-local-governance-nepal.aspx.

[24] Kyrgyz Republic, (2011): Law of the Kyrgyz Republic about Local Self-Government. Available at http://cis-legislation.com/document.fwx?rgn=45734.

[25] K Topfer and H. Hoffschulte, (1998): "Towards a World Charter of Local Self Government" Nairobi: United Nations Centre for Human Settlements (Habitat).

[26] Council of Europe (1985): "European Charter of Local Self-Government". Available at http://conventions. coe.int/treaty/en/treaties/ html/122. 